\title{
Plankton biodiversity around the Salento Peninsula (South East Italy): an integrated water/sediment approach*
}

\author{
SALVATORE MOSCATELLO ${ }^{1}$, FERNANDO RUBINO², ORESTINA D. SARACINO², \\ GIOVANNI FANELLI ${ }^{2}$, GENUARIO BELMONTE ${ }^{1}$ and FERDINANDO BOERO ${ }^{1}$ \\ ${ }^{1}$ Dipartimento di Scienze e Tecnologie Biologiche ed Ambientali, ULR CoNISMa, Stazione di Biologia Marina, \\ Università di Lecce, 73100 Lecce, Italy. E-mail: genuario.belmonte@ unile.it \\ ${ }^{2}$ Istituto per l'Ambiente Marino Costiero, sez. Talassografico “A. Cerruti” - CNR, Via Roma 3, 74100 Taranto, Italy.
}

\begin{abstract}
SUMMARY: The microplankton community was studied at 9 sites (29 sampling stations) along the Salento Peninsula (SE Italy). Integrated samplings from both the water column (to collect active stages), and sediments (to collect resting stages), were carried out. More than 400 taxa were recognised in total. As for phytoplankton, 64 taxa were new records from the area. In particular, 16 of them were found only as resting stages in the sediments. A harbour, a coastal lake, and a submerged cave were investigated to understand the role of confined or sheltered environments in the accumulation of resting stages. The harbour and the lake were found to be biodiversity reservoirs, due to the abundance of resting stages in their sediments. Only few species were found both in the water column, as plankton, and in the sediments, as resting stages. Furthermore, the most abundant species in the water column were not equally dominant as resting stages in the sediments. This suggests that species other than those observed in the plankton during the present work (i.e., those found as dominant among resting stages in the sediments) dominated the plankton in the past. Furthermore, they could dominate the future plankton, with multiannual cycles, starting from sediment reservoirs. The search for resting stages in the sediment, thus, is useful to discover temporarily rare species, because species persist in the sediments as resting stages for longer periods than those spent as active stages in the plankton.
\end{abstract}

Key words: resting stages, cyst banks, microzooplankton, phytoplankton, Central Mediterranean.

RESUMEN: Biodiversidad del Plancton en aguas de la PENínsula de Salento (Italia Sudoriental): Una aproximaCIÓN QUE INTEGRA AGUA Y SEDIMENTO. - Se estudió la comunidad microplanctónica en 9 localidades (29 estaciones de muestreo) a lo largo de la península de Salento (Italia sudoriental). Se realizaron muestreos integrados de la columna de agua (para recolectar estados activos) y de los sedimentos (para recolectar estados quiescentes). En total, se reconocieron más de 400 táxones. En lo que respecta al fitoplancton, 64 táxones fueron nuevas citas para la zona. En particular, 16 de ellos se encontraron únicamente como estados quiescentes en el sedimento. Se estudiaron un puerto, un lago costero y una cueva submarina para comprender el papel de los ambientes confinados o resguardados en la acumulación de estados de quiescencia. Se encontró que el puerto y el lago eran depósitos de biodiversidad, debido a la abundancia de estados quiescentes en sus sedimentos. Sólo unas pocas especies se encontraron a la vez en la columna de agua, como plancton, y en los sedimentos, como estados quiescentes. Además, las especies más abundantes en la columna de agua no eran igualmente dominantes como estados quiescentes en los sedimentos. Esto sugiere que el plancton del pasado estaba dominado por otras especies (es decir, las que son más abundantes entre los estados quiescentes en el sedimento), distintas de las que se han observado en el plancton durante el presente trabajo. Además, dichas especies podrían dominar el plancton futuro, con ciclos multianuales, iniciados a partir de los depósitos de los sedimentos. Así, pues, la búsqueda de estados quiescentes en el sedimento es útil para descubrir especies que son raras a la escala temporal, porque las especies persisten como estados de quiescencia durante períodos más largos que los que pasan como estados activos en el plancton.

Palabras clave: estados de quiescencia, bancos de cistes, microzooplancton, Mediterráneo central. 


\section{INTRODUCTION}

Coastal marine microplankton (both phyto- and zooplankton) is composed of species with short life cycles, strongly affected by seasonal fluctuations in abiotic conditions (see Krsinic, 1998, for South Adriatic area). In marine coastal environments, monospecific blooms are often the rule, with abundance-rarity alternate periods shown by many species on a multiannual scale. The high diversity of plankton derives precisely from this kind of pattern (Boero, 1994). An extreme case is the complete disappearance of species from the water column, with suspension of active life for long periods (from a single season to many years; Boero, 1994; Giangrande et al., 1994). During these periods, species are not in the water column but they are "elsewhere" (generally in the sediments) as lethargic, or encysted forms. Such a habitat shift represents a still underestimated transfer of living matter from pelagos to benthos (Boero et al., 1996). Dale's (1983) "benthic" point of view in considering the ecology of planktonic dinoflagellates is now embracing many other plankton groups, also due to the widespread use of palynological methods in the study of surface sediments at the sea bottom. Especially in marine coastal areas, the search for plankton-derived benthic cysts aims at integrating the classical approach to the study of plankton in the water column. The spread of this methodological innovation (Uye, 1985; Montresor et al., 1998; Rubino et al., 1998; Kim and Han, 2000) highlights the role of benthic resting stages in plankton dynamics.

At present, the production of resting stages is of paramount importance for the understanding of coastal plankton ecology (Marcus and Boero, 1998). The resting stages of different phyla and kingdoms show similar morphologies (e.g. a spiny or differently sculptured surface), suggesting an evolutionary convergence to optimise survival during periods of lethargy that may often be longer than the "active" life of individual organisms (Belmonte et al., 1997). Notwithstanding this, the morphological variability is sufficient to recognise most resting stages even at the species level (see Matsuoka and Fukuyo, 2000, and Nehring, 1997, for dinoflagellates; Marcus, 1990; Rubino et al., 2000, for metazoans). The studies carried out to quantify the ecological impact of this life-cycle trait showed that sediments of confined marine environments host up to hundreds of millions of resting stages per square metre (Belmonte et al., 1995). The sediments of open coastal areas are not so rich (for metazoan resting eggs see Lindley, 1992; Lutz et al., 1992). Therefore, sediments of sheltered areas are considered "reservoirs of potential biodiversity" (Belmonte et al., 1995; Rubino et al., 2000), as possibly are also marine canyons (Della Tommasa et al., 2000), and could play the same ecological role as soil seed banks do on land (Leck et al., 1989). Due to this similar role, Giangrande et al. (1994) talked about "marine seed-banks", and Marcus and Boero (1998) talked about "marine banks of eggs, spores, or cysts", to refer to these assemblages of resting stages in the marine bottom sediments.

The maximum length of dormancy of marine resting stages is poorly known. They represent a strategy to overcome adverse conditions; nevertheless, some recent studies provide estimates of exceptionally extended dormancy to tens of years both for Metazoa and Protista (Marcus et al., 1994; Belmonte et al., 1999). This is probably the rule also for a minority of cysts in the resting pool of each generation according to a "bet hedging" strategy (Philippi and Seger, 1989). This suggests that plankton species, at temperate latitudes, could occur (and be recorded) in the sediments as resting stages for periods longer than in the water column, where usually they have a seasonal presence, or a multi-annual cycle of abundance-rarity.

The analysis of benthic cysts can lead to the discovery of rare species (or those which occur in the water column for short periods), enhancing the knowledge of the plankton biodiversity (Rubino et al., 2000; Rubino et al., 2002).

The present study, performed in the framework of the INTERREG II Greece-Italy project, aims at the evaluation of plankton biodiversity along the Salento Coast (S-E Italy). The microplankton has been chosen because its dimensional range comprises most "cyst-producing" species (Dinophyta, Ciliophora, Rotifera). The planning of an integrated water-sediment sampling approach on a seasonal time scale has been carried out to show the possible successions between planktonic and benthic stages of the same species.

\section{MATERIAL AND METHODS}

Four cruises were carried out along the Salento Peninsula (South East Italy; Southern Adriatic Northern Ionian seas) from Torre Guaceto (Brindisi) to Porto Cesareo (Lecce) on the oceanographic ship 


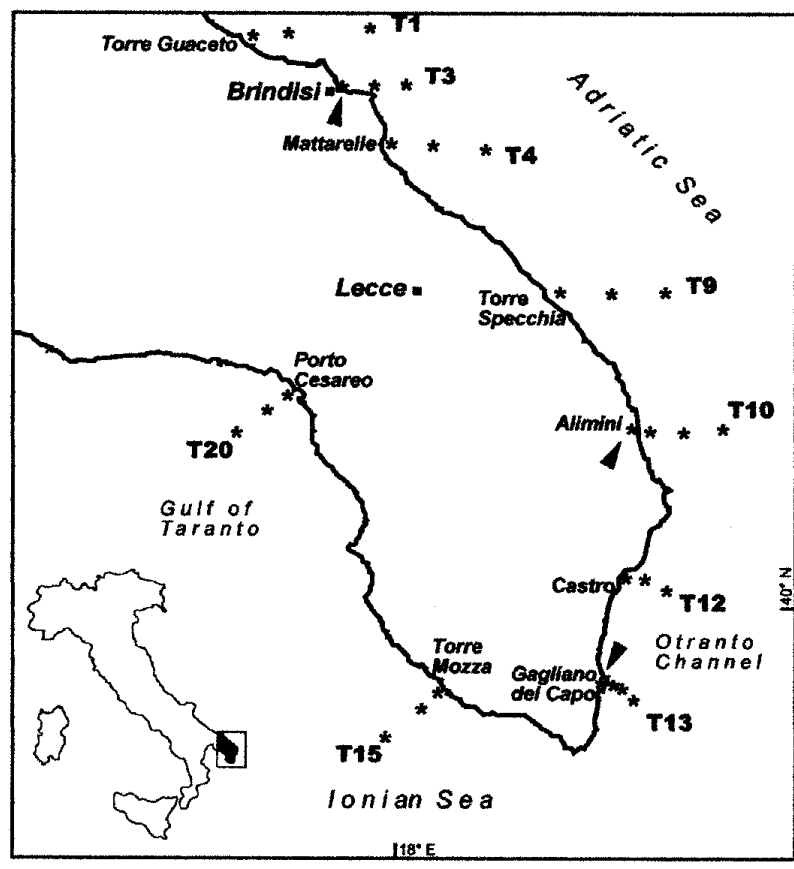

FIG. 1. - Map of the study area (Salento Peninsula, SE Italy). Asterisks indicate sampling stations, along 9 off shore transects (T1$\mathrm{T} 20)$. Arrows point to confined stations.

Coopernaut Franca in March, May, September, and December 2000. The studied coastline, about 250 $\mathrm{km}$ long, was divided in 20 sampling areas. The microplankton community was studied in 9 of these areas, separated by intervals of about $30 \mathrm{~km}$ (Fig. 1). At each area (numbered as 1, 3, 4, 9, 10, 12, 13, 15, 20), samples were collected along one transect off shore $(\mathrm{T})$, at three sampling stations $(\mathrm{A}, \mathrm{B}, \mathrm{C})$ corresponding to the isobaths of $-10,-20$, and $-50 \mathrm{~m}$.

Moreover, a confined station was added to the Alimini (T10), and Gagliano del Capo (T13) transects, respectively the brackish lake Alimini Grande and the submarine cave Grotta di Ciolo. A third sheltered station was the Brindisi harbour, already included in the T03 transect (Table 1). At each station, water samples for phytoplankton and microzooplankton (1 and 10 litres respectively) were collected at two depths ( $2 \mathrm{~m}$ below the surface and $2 \mathrm{~m}$ above the bottom) using a multi sampler equipped with 121 Niskin bottles. At the confined and $-10 \mathrm{~m}$ stations, the sampling was carried out only at the $-2 \mathrm{~m}$ level.

Phytoplankton samples were fixed in situ with neutralised ( $\mathrm{pH}$ 7.3) formaldehyde to a final dilution of $1.6 \%$. Subsamples of $100 \mathrm{ml}$ were analysed with an inverted microscope at 400x magnification following the Utermöhl (1958) methodology. Cells were counted according to Zingone et al. (1990). Data are presented in number of cells per litre. Microzooplankton samples were obtained by filtering, in situ, 101 of seawater through a $10 \mu \mathrm{m}$ sieve. The retained material was diluted in $150 \mathrm{ml}$ of filtered $(0.45 \mu \mathrm{m})$

TABLE 1. - Locality, transect and station abbreviation, depth and geographic coordinates of sampling stations during the four cruises. The indication of sediment sampler type refers to March and September 2000 only.

\begin{tabular}{|c|c|c|c|c|c|}
\hline locality & transect & station & lat. $(\mathrm{N})$ & long. (E) & sediment sampler \\
\hline \multirow[t]{3}{*}{ Torre Guaceto } & $\mathrm{T} 1$ & A $-10 m$ & $40^{\circ} 43^{\prime} 12$ & $17^{\circ} 48^{\prime} 70$ & grab \\
\hline & & B $-20 m$ & $40^{\circ} 43^{\prime} 10$ & $17^{\circ} 49^{\prime} 37$ & grab \\
\hline & & C $-50 m$ & $40^{\circ} 43^{\prime} 19$ & $17^{\circ} 51^{\prime} 10$ & multicorer \\
\hline \multirow[t]{3}{*}{ Brindisi } & T3 & A Harbour & $40^{\circ} 38^{\prime} 63$ & $17^{\circ} 56^{\prime} 69$ & multicorer \\
\hline & & B - $-20 m$ & $40^{\circ} 39^{\prime} 56$ & $17^{\circ} 59^{\prime} 62$ & multicorer \\
\hline & & C $-50 m$ & $40^{\circ} 40^{\prime} 12$ & $17^{\circ} 59^{\prime} 76$ & multicorer \\
\hline \multirow[t]{3}{*}{ Mattarelle } & $\mathrm{T} 4$ & A $-10 m$ & $40^{\circ} 34^{\prime} 34$ & $18^{\circ} 02^{\prime} 97$ & grab \\
\hline & & B -20m & $40^{\circ} 32^{\prime} 82$ & $18^{\circ} 06^{\prime} 37$ & grab \\
\hline & & C $-50 m$ & $40^{\circ} 35^{\prime} 36$ & $18^{\circ} 09^{\prime} 67$ & multicorer \\
\hline \multirow[t]{3}{*}{ Torre Specchia } & T9 & A $-10 m$ & $40^{\circ} 19^{\prime} 35$ & $18^{\circ} 23^{\prime} 18$ & grab \\
\hline & & B $-20 m$ & $40^{\circ} 19^{\prime} 37$ & $18^{\circ} 23^{\prime} 35$ & grab \\
\hline & & C $-50 m$ & $40^{\circ} 19^{\prime} 89$ & $18^{\circ} 23^{\prime} 84$ & multicorer \\
\hline \multirow[t]{4}{*}{ Alimini } & $\mathrm{T} 10$ & $\varnothing$ Lake & $40^{\circ} 12^{\prime} 06$ & $18^{\circ} 27^{\prime} 00$ & handcorer \\
\hline & & A $-10 m$ & $40^{\circ} 12^{\prime} 16$ & $18^{\circ} 27^{\prime} 20$ & grab \\
\hline & & B $-20 m$ & $40^{\circ} 11^{\prime} 95$ & $18^{\circ} 28^{\prime} 26$ & grab \\
\hline & & C $-50 m$ & $40^{\circ} 11^{\prime} 26$ & $18^{\circ} 30^{\prime} 18$ & multicorer \\
\hline \multirow[t]{3}{*}{ Castro } & $\mathrm{T} 12$ & A $-10 m$ & $39^{\circ} 59^{\prime} 38$ & $18^{\circ} 25^{\prime} 01$ & grab \\
\hline & & B -20m & $39^{\circ} 59^{\prime} 57$ & $18^{\circ} 25^{\prime} 50$ & grab \\
\hline & & C $-50 m$ & $39^{\circ} 58^{\prime} 94$ & $18^{\circ} 26^{\prime} 64$ & multicorer \\
\hline Gagliano del & $\mathrm{T} 13$ & $\varnothing$ Cave & $39^{\circ} 50^{\prime} 63$ & $18^{\circ} 23^{\prime} 18$ & handcorer \\
\hline \multirow[t]{3}{*}{ Capo } & & A $-10 m$ & $39^{\circ} 51^{\prime} 26$ & $18^{\circ} 23^{\prime} 55$ & grab \\
\hline & & B - $-20 m$ & $39^{\circ} 51,52$ & $18^{\circ} 23^{\prime} 65$ & grab \\
\hline & & C - $-50 m$ & $39^{\circ} 50^{\prime} 84$ & $18^{\circ} 23^{\prime} 65$ & multicorer \\
\hline \multirow[t]{3}{*}{ Torre Mozza } & $\mathrm{T} 15$ & A $-10 m$ & $39^{\circ} 50^{\prime} 62$ & $18^{\circ} 07^{\prime} 44$ & grab \\
\hline & & B $-20 m$ & $39^{\circ} 50^{\prime} 44$ & $18^{\circ} 06^{\prime} 47$ & grab \\
\hline & & C $-50 m$ & $39^{\circ} 49^{\prime} 97$ & $18^{\circ} 04^{\prime} 73$ & multicorer \\
\hline \multirow{3}{*}{ Porto Cesareo } & $\mathrm{T} 20$ & A $-10 m$ & $40^{\circ} 15^{\prime} 40$ & $17^{\circ} 52^{\prime} 76$ & grab \\
\hline & & B -20m & $40^{\circ} 14^{\prime} 87$ & $17^{\circ} 53^{\prime} 39$ & grab \\
\hline & & C $-50 m$ & $40^{\circ} 10^{\prime} 56$ & $17^{\circ} 49^{\prime} 01$ & grab \\
\hline
\end{tabular}


seawater, and preserved with a neutralised $(\mathrm{pH} 7.3)$ formaldehyde solution to a final dilution of $1.6 \%$. From the whole sample, $60 \mathrm{ml}$ were subdivided in the 6 wells (each of $10 \mathrm{ml}$ ) of a culture plate and observed with an inverted microscope at 200x magnification, after sedimentation. Data are presented as number of individuals per litre.

Identification was carried out at species level. This was not possible for some nanoplanktonic taxa and some larval stages. In such cases the specimens were grouped in "categories" (e.g. naked and thecate dinoflagellates, Phytoflagellata $<10 \mu \mathrm{m}$, nauplii, copepodids).

Resting stages were searched for in sediments collected in March and September with a Bowers \& Connelly multicorer (mod. Mini) or a Van Veen grab at each station (see Table 1). Three independent replicates of the 2 top $\mathrm{cm}$ of sediment were collected on board, by means of hand-corers (inner $\varnothing, 2.7$ $\mathrm{cm}$ ), in order to obtain quantitative data, and immediately stored in the dark at $-20^{\circ} \mathrm{C}$. In the laboratory, sediment samples (aliquots from 5 to $12 \mathrm{~cm}^{3}$ ) were sieved (see Rubino et al., 2000 for methods), obtaining a fine-grained sediment fraction $(20-75 \mu \mathrm{m})$ mainly containing Protista cysts, and another one (75-200 $\mu \mathrm{m})$ with Metazoa resting eggs. Identification and counting of resting stages were performed only on viable specimens (i.e., full and not damaged) by means of an inverted microscope at 320x magnification for Protista cysts and 100x magnification for Metazoa resting eggs. The sub-samples analysed were $1 / 40$ of the fine-grained fraction and $1 / 20$ of the $75-200 \mu \mathrm{m}$ one. These aliquots were representative of the whole sample according to a preliminary data analysis (data not shown), that was based on the relationship between the standard error of the number of taxa and the subsample volume (Bros and Cowell, 1987).

Resting stages were classified on the basis of their morphology (diameter, colour, shape, type of surface structures). Data are presented as number of resting stages (cysts, or eggs) per $\mathrm{cm}^{3}$ of wet sediment.

Analysis of variance (ANOVA) was used to test differences of plankton taxa abundance among sampling times and stations. Factor "Station" (3 levels: $-10,-20,-50 \mathrm{~m}$ ) was considered as fixed and orthogonal to the random factor "Time" (4 levels: March, June, September, and December). Data from confined stations were not considered, and the Brindisi transect was omitted because it contained a confined station (the harbour). Data from $\mathrm{B}$ and $\mathrm{C}$ stations (corresponding to -20 and $-50 \mathrm{~m}$ isobaths) of each transect were averages of surface and bottom samples.

Differences of resting stage abundance were tested by two-way ANOVA, with "Area" (transect) and "Station" as fixed and orthogonal factors. Factor "Area" had 5 levels (only data from transects T04, T09, T10, T12, and T13 were used since they were homogeneous with regard to the number of samples and replicates). Cochran's $C$ test was used to check the assumption of homogeneity of Variance (Winer, $1971)$ and, when it was violated, data were $\log (\ln$ $\mathrm{x}+1)$ transformed. The SNK test was used for an $a$ posteriori multiple comparison of means.

Bi-dimensional representations of the statistical analysis carried out on the plankton communities in the water column (phytoplankton and microzooplankton) and in the sediments (resting stages) were obtained by non-parametric multidimensional scaling (nMDS) and cluster analysis. For phytoand microzooplankton the data matrix contained averaged values (resulting from replicates as indicated above). Both analyses were performed by PRIMER 5 (Clarke and Warwick, 1994) on the Bray-Curtis similarity matrix based on log-transformed data $(\log x+1)$ in order to severely downweight the importance of the very abundant species so allowing the less dominant, and even the rare species, to play some role in determining similarity among samples.

\section{RESULTS}

\section{Phytoplankton}

A total of 172 samples were analysed, and 155 categories were recognised; 90 of them were dinoflagellates (86 of them at species level), 51 diatoms (all at species level), 6 coccolithophorids (5 at species level), and 8 (5 at species level) were grouped as "other phytoplankton" (Table 2).

Total abundance per sample ranged from 12,000 (September, T04 C) to 278,000 cells $1^{-1}$ (June, T10 lake). Diatoms reached the highest values $(258,000$ cells $1^{-1}$ ) at T10 lake, in June; dinoflagellates peaked

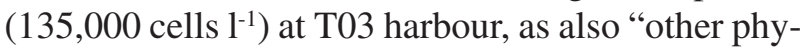
toplankton" did $\left(15,000\right.$ cells $\left.1^{-1}\right)$, while coccolithophorids were most abundant in March $(67,000$ cells ${ }^{-1}$ ) at T15 B. No significant abundance-differences were recorded between seasons and stations (Table 3), if sheltered stations were not considered. The maximum (116) and the minimum (82) number 
TABLE 2. - List of phytoplankton taxa/categories collected in the water column during the four oceanographic surveys (M=March, J=June, $\mathrm{S}=$ September, $\mathrm{D}=$ December 2000). Black dots indicate the presence of the taxon/category in samples of each cruise. Asterisks indicate new records for the area.

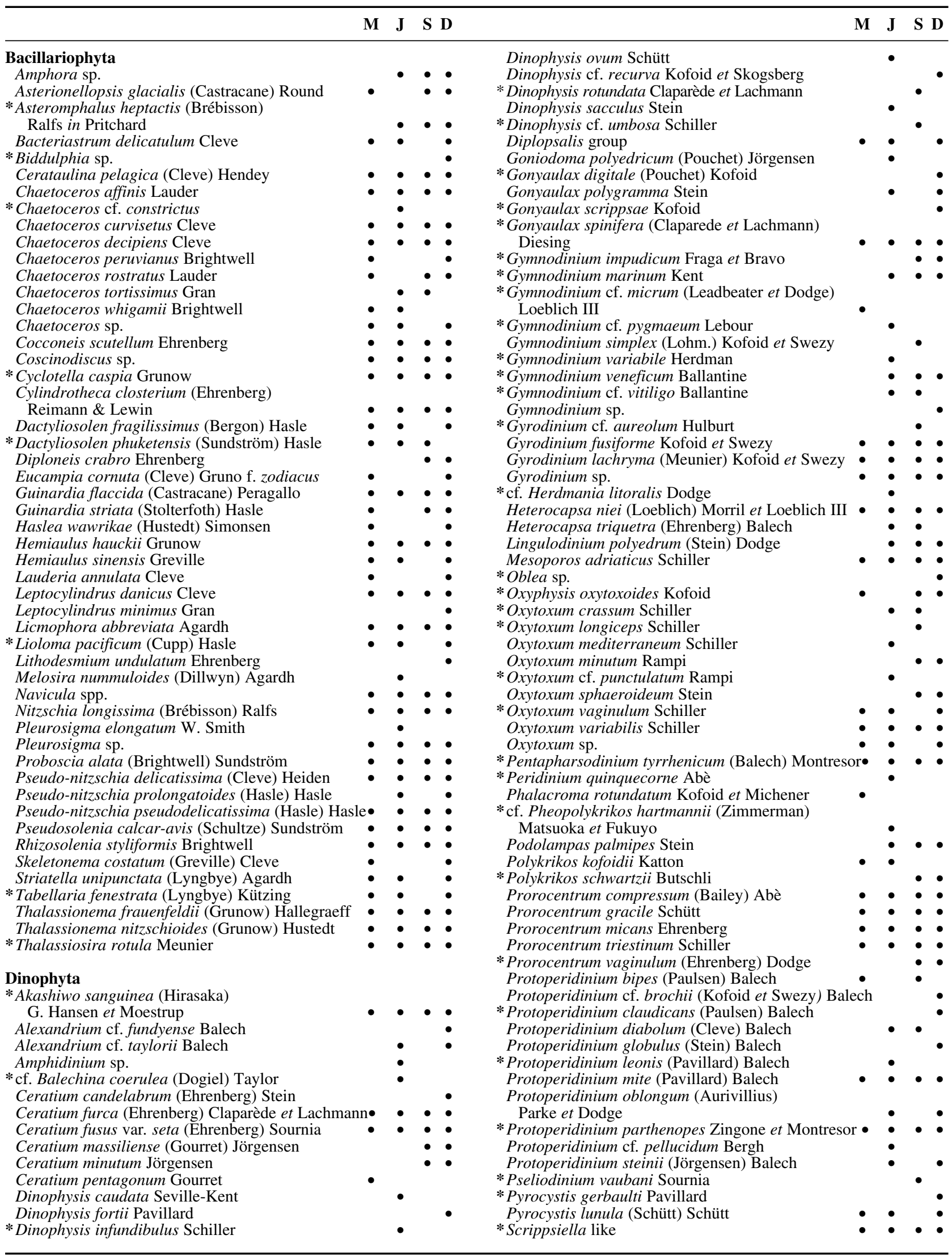


TABLE 2 (Cont.). - List of phytoplankton taxa/categories collected in the water column during the four oceanographic surveys (M=March, J=June, S=September, D=December 2000). Black dots indicate the presence of the taxon/category in samples of each cruise. Asterisks indicate new records for the area.

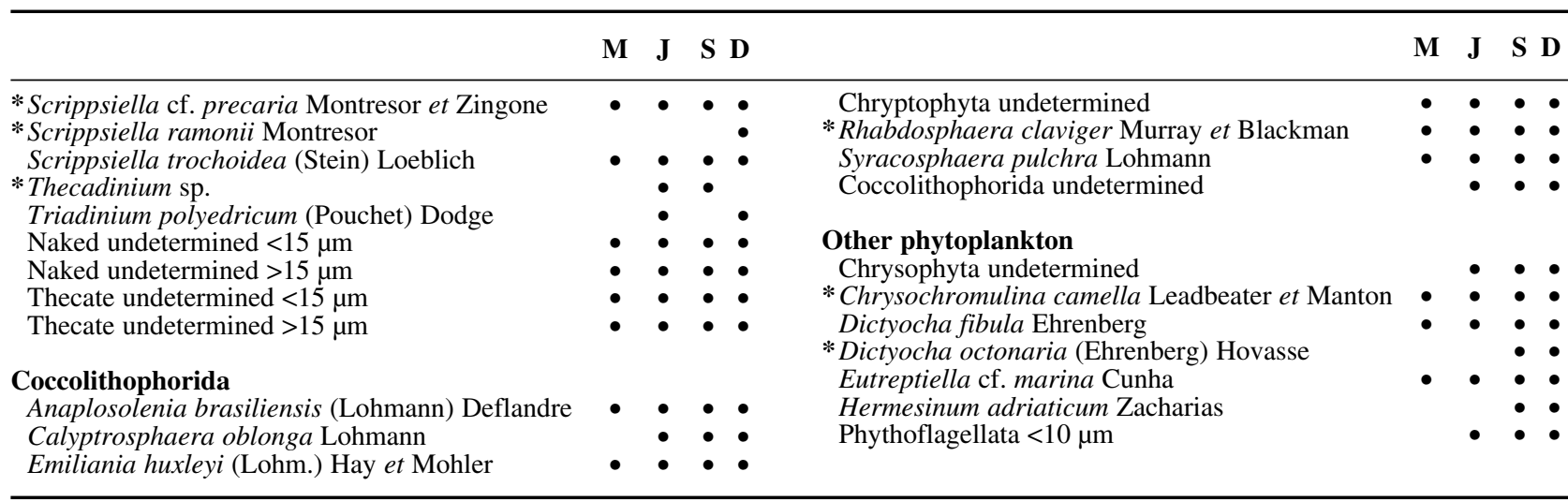

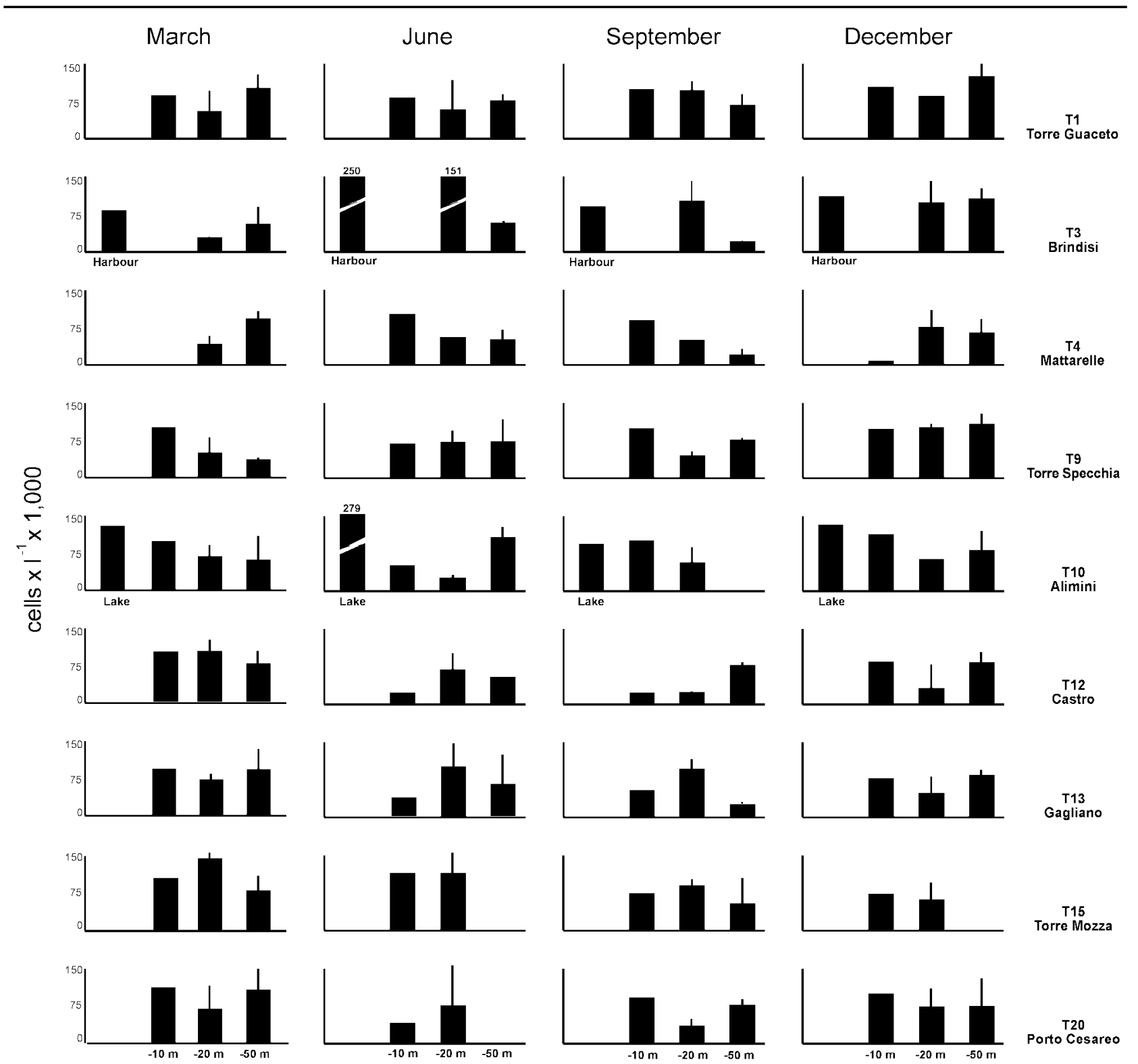

FIG. 2. - Phytoplankton abundance (thousands cells per litre) at 9 transects along the Salento Peninsula, in seasonal sampling periods (March, June, September, December 2000). The first bar of each histogram represents a confined station (harbour or coastal lake). The next three bars represent samples from the off shore transect at 10, 20 and $50 \mathrm{~m}$ depth. 
TABLE 3. - Analysis of variance of the effects of the sampling date (Time) and the sampling Station on total phytoplankton abundance. Brindisi transect (T03) and confined stations were not considered.(ns: $\mathrm{P}>0.05 ; *: \mathrm{P}<0.05$; ** $\mathrm{P}<0.01)$.

\begin{tabular}{lcccc}
\hline & & \multicolumn{3}{c}{ Phytoplankton } \\
Source of variation & Df & MS & & P \\
\hline Time & 3 & 6883979.6493 & 1.86 & $\mathrm{~ns}$ \\
Station & 2 & 606423.5729 & 4.18 & $\mathrm{~ns}$ \\
Time x Station & 6 & 7671432.3785 & 0.42 & $\mathrm{~ns}$ \\
Cochran's test & \multicolumn{4}{c}{ C $=0.229$ P $>0.05$} \\
Transformation & \multicolumn{4}{c}{ None } \\
\end{tabular}

of categories were recorded (in total) in December and March respectively.

Dinoflagellates were the most diversified group (up to 59 taxa, in June) in all seasons, except in March, when diatoms reached 40 taxa. "Phytoflagellates $<10 \mu \mathrm{m}$ " were the most abundant category at all sampling dates, reaching up to $51 \%$ of the total cell number.

Generally phytoplankton abundance was homogeneous in the whole region in each period, except for the confined stations of Brindisi harbour and the

\section{March}
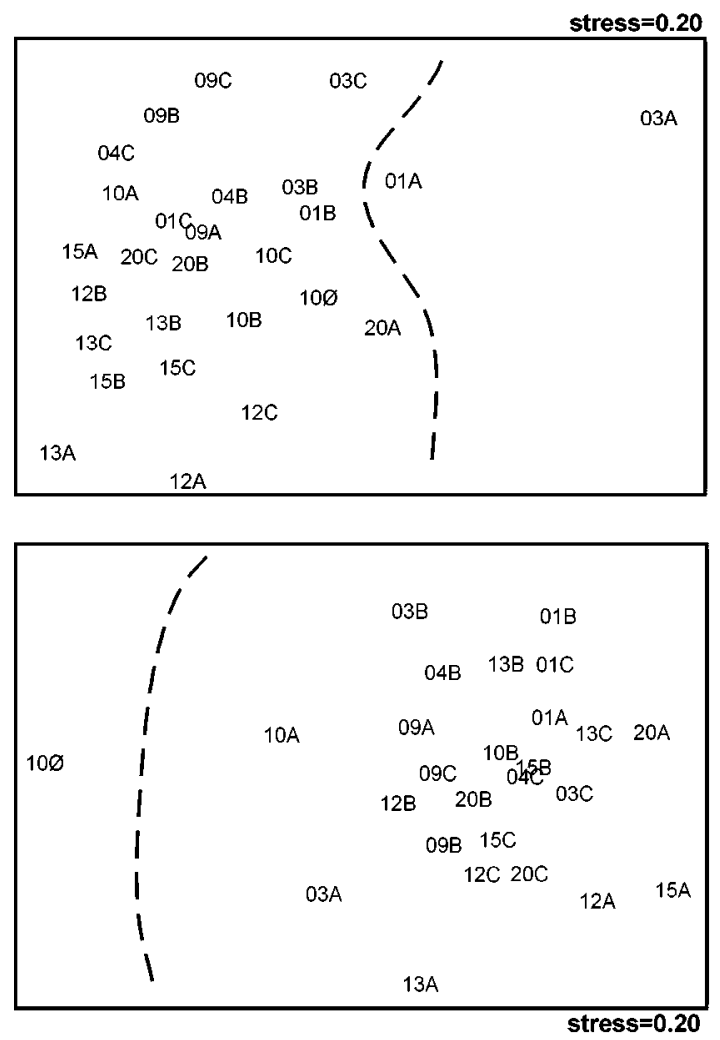

September
Alimini lake. At these stations all the main taxa showed abundance values higher than in the open water stations of the same transect during the whole study period (Fig. 2).

No ubiquitous species (i.e., present in all samples of the same time) were found. Pleurosigma sp. (diatoms) was the most common species in March (74\% of the stations), Cocconeis scutellum (diatoms) and Oxytoxum sp. (dinoflagellates) were the most common in June (61.5\%), and Proboscia alata (diatoms) was common in September (77\%) and December (84.6\%). Only 54 of the 155 categories were recorded during the entire study period, at least in one sample (Table 2).

Cluster analysis and nMDS (useful stress values) highlighted a complex variability of phytoplankton communities along the coast (Fig. 3), and in different periods. The main characterisation derives from samples collected at Brindisi harbour (03 A) which segregated from the others in $3 / 4$ of the cases. This segregation was probably due to the dominance of few species of dinoflagellates (in March, and December) or diatoms (in June).
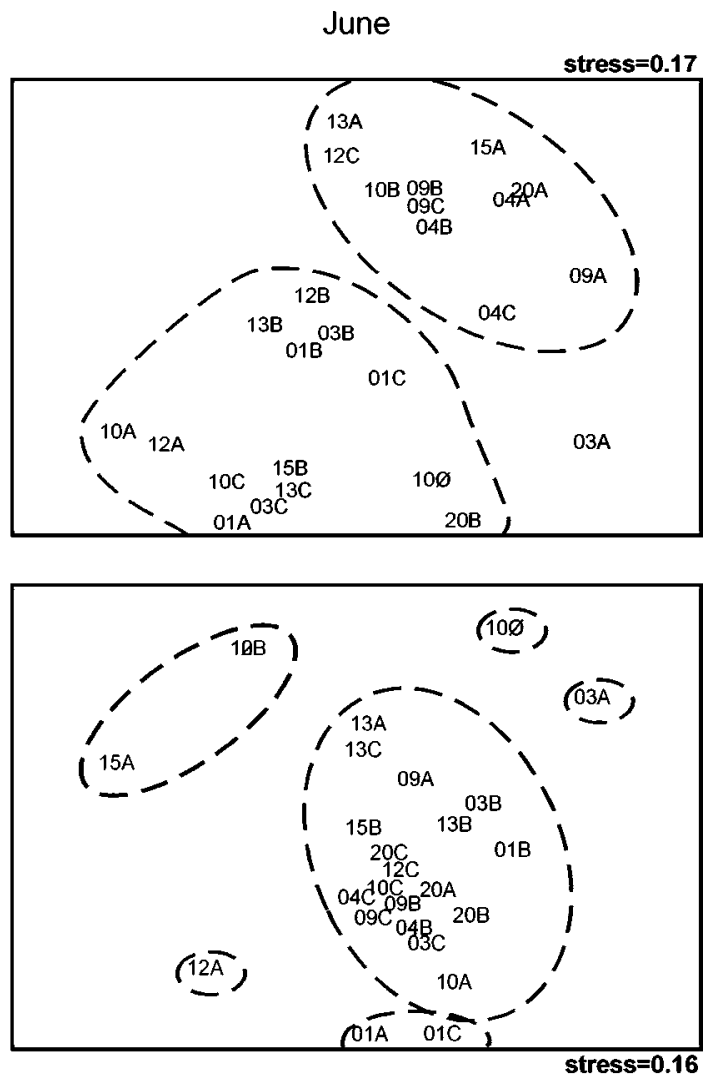

December

FIG. 3. - Non-parametric Multidimensional Scaling (nMDS) representation of phytoplankton samples collected in March, June, September and December 2000, with superimposed clusters at similarity level of $40 \%$ (dashed line). Numbers (01-20) represent transects. A, B, C, represent stations from near coast to open sea (at isobaths of $-10 \mathrm{~m},-20 \mathrm{~m},-50 \mathrm{~m})$. $\varnothing$ indicates confined station at Alimini (10) and Gagliano del Capo (13) transects. The confined station of the Brindisi transect (harbour) is 03A. 
TABLE 4. - List of microzooplankton categories collected in the water column during the four oceanographic surveys (M=March, J=June, $\mathrm{S}=$ September, $\mathrm{D}=$ December, 2000). Black dots indicate the presence of the category in at least one sample of each cruise.

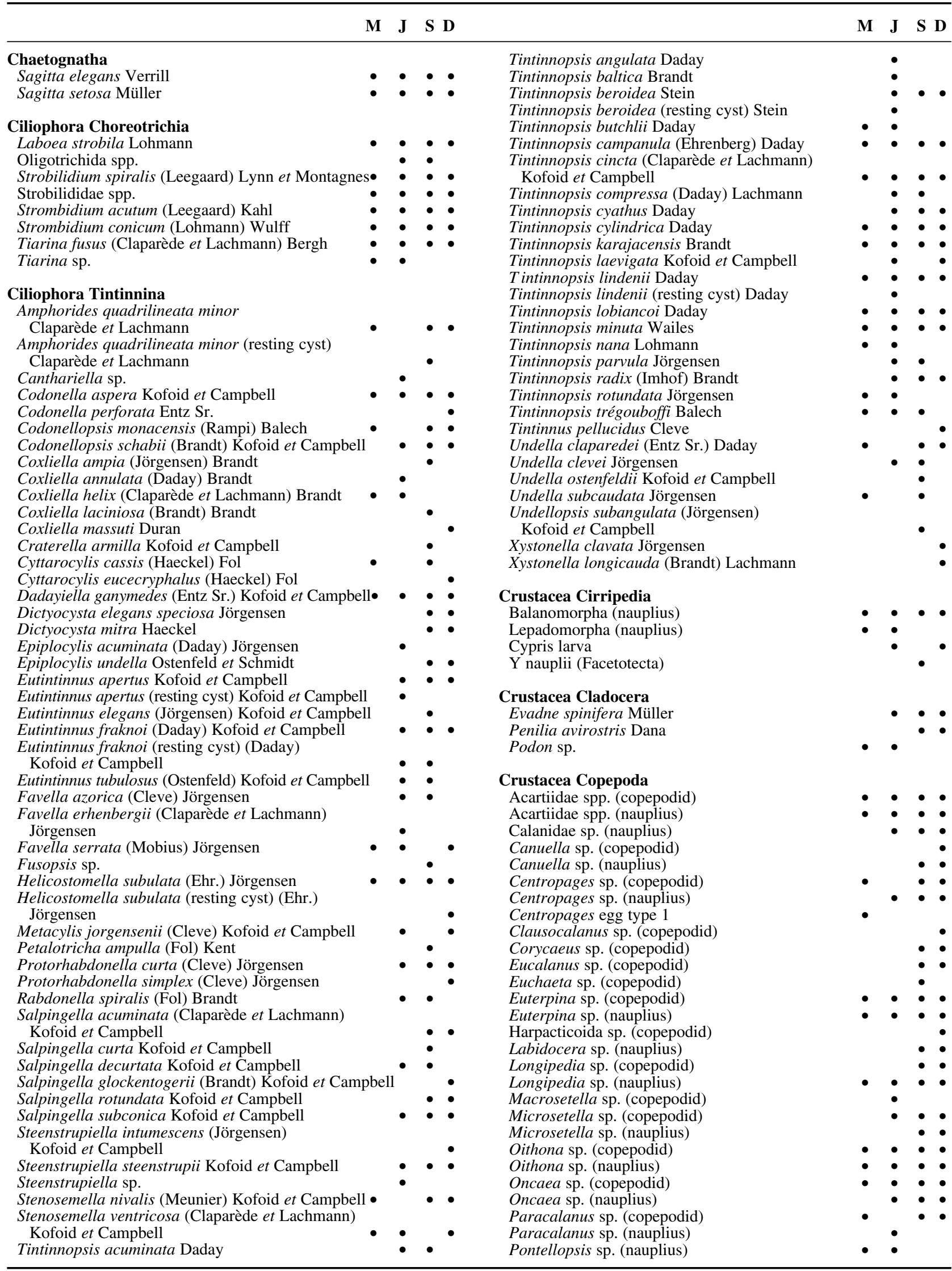


TABLE 4 (Cont.). - List of microzooplankton categories collected in the water column during the four oceanographic surveys (M=March, J=June, S=September, D=December, 2000). Black dots indicate the presence of the category in at least one sample of each cruise.

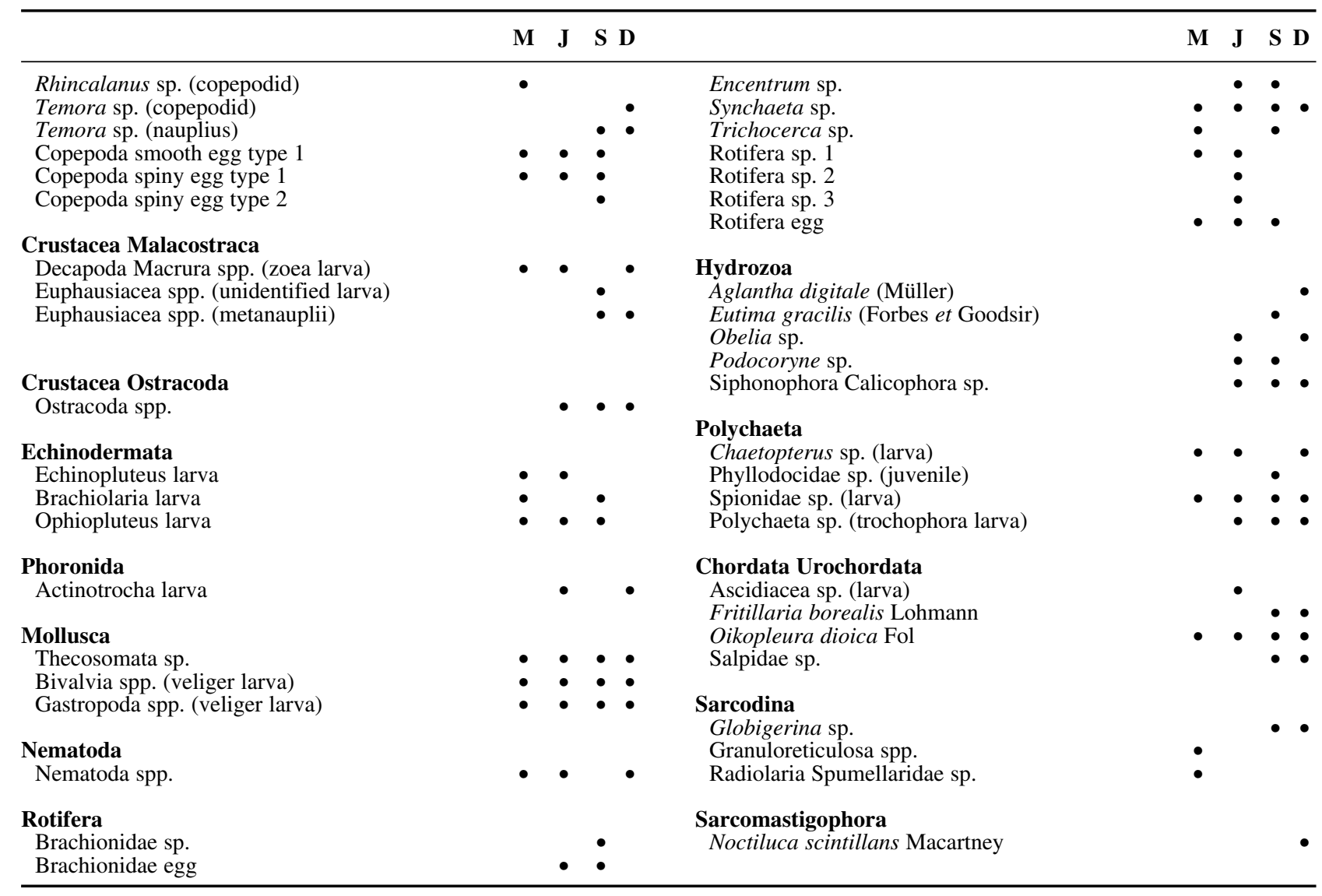

With regard to the phytoplankton community composition, 48 species (about 31\%) were new records for the study area.

Four potentially toxic species were found: Pseudo-nitzschia pseudodelicatissima among diatoms (in Brindisi harbour), and dinoflagellates Akashiwo sanguinea (in the Alimini lake), Alexandrium fundyense (Torre Guaceto, T01 A station) and Phalacroma rotundatum (Brindisi harbour).

\section{Microzooplankton}

A total of 174 samples were analysed; 167 categories (129 at the species level) were identified, mainly represented by ciliates (86) and crustaceans (45; Table 4). The total density ranged from 3 (June, T13 cave) to 8,913 ind. $1^{-1}$ (March, T03 harbour; Fig. 4). Tintinnina, the best-represented group, reached the highest values $\left(8,686\right.$ ind. $\left.1^{-1}\right)$ in March at Brindisi harbour, where Copepoda had their abundance maximum in June (633 ind. $1^{-1}$ ). The microzooplankton community showed marked abundance-differences among seasons, but homogeneity was recorded among non confined stations (Fig. 5).
In September 113 categories of microzooplankton were recorded in total, and only 67 in March.

With regard to single categories, Helicostomella subulata (Tintinnina) was the most abundant in a single sample $\left(6,066\right.$ individuals $1^{-1}$, Brindisi harbour, March); it was reported only from Brindisi (T03) and Torre Mattarelle (T04) transects (with huge prevalence in Brindisi harbour). Tintinnopsis compressa (Tintinnina) was the most abundant category in June (353 individuals $\mathrm{l}^{-1}$, T10 C, surface), Spionidae (Polychaeta) larvae (543 individuals $1^{-1}$, T10 $\varnothing=$ Alimini lake) in September, and Oithonidae (Copepoda) nauplii (28 individuals $1^{-1}$, T03 A = Brindisi harbour) in December.

There were not ubiquitous categories but Oikopleura sp. (Larvacea) was the most common category in March (found in more than $90 \%$ of samples), and Eutintinnus fraknoi (Tintinnina) in June (95\% of samples). In September, the ciliates Strombidium acutum $(78 \%)$ and Tiarina fusus $(71 \%)$ were the most common categories. Finally, in December, Oithonidae nauplii occurred in the $98 \%$ of samples. Only 32 of the 167 categories were found during the entire study period (Table 4), at least in one sample. 


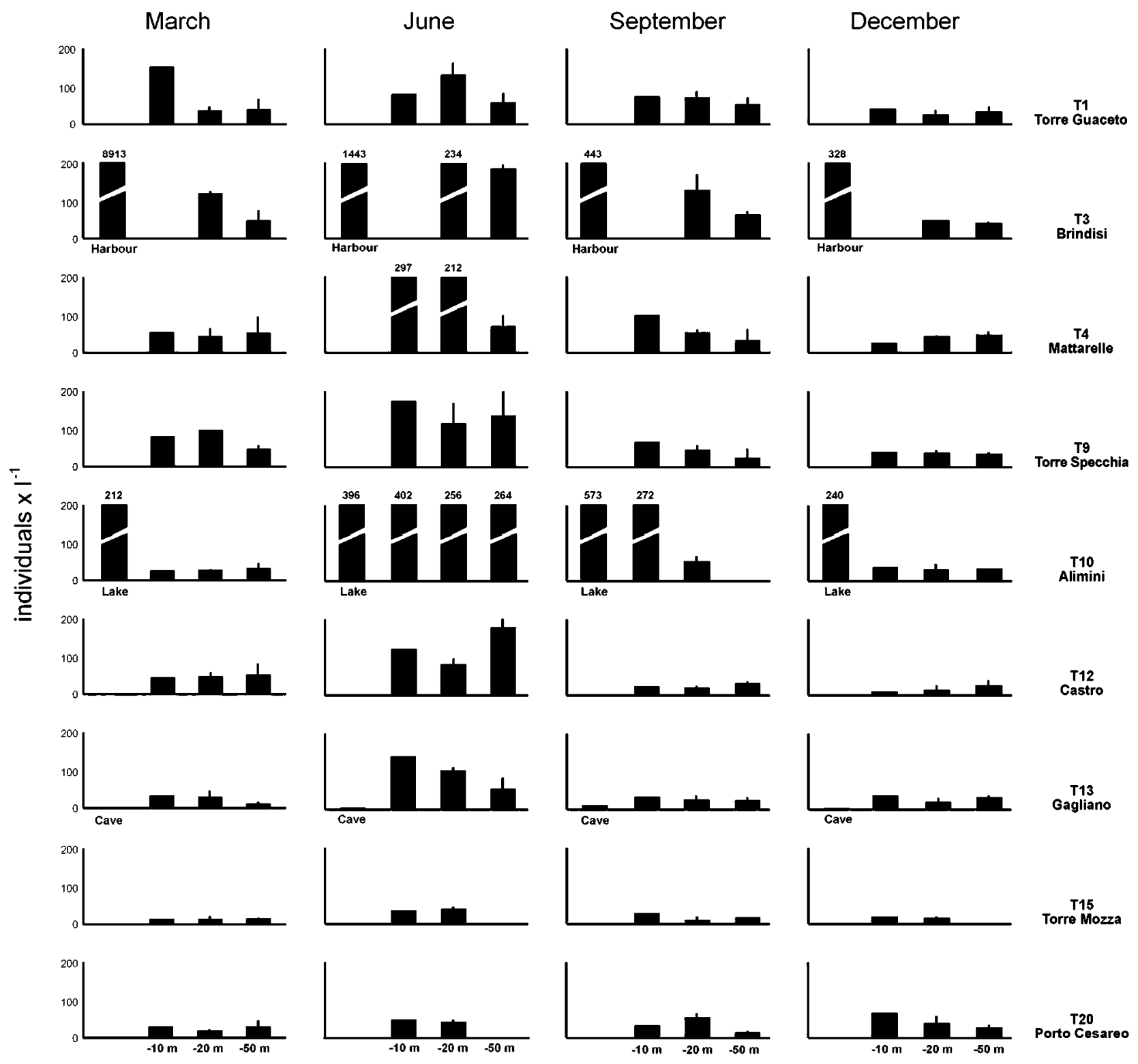

FIG. 4. - Microzooplankton abundance (individuals per litre) at 9 transects along the Salento Peninsula, in the different sampling periods (March, June, September, December 2000). Note that when available the confined station is always on the left.

At the confined station of the Gagliano del Capo transect (T13 $\varnothing$, the cave), microzooplankton samples, unlike those of the other two confined stations (Brindisi harbour and the Alimini lake), were particularly poor (3-10 ind. $\left.1^{-1}\right)$.

Cluster analysis and nMDS ordination (with stress values lower than both phytoplankton and cysts nMDS plots) showed that microzooplankton communities of the three confined stations grouped separately from each other, and from all the remaining stations, in all sampling dates (Fig. 5). Samples collected within the Grotta di Ciolo (T13 $\varnothing$ ) were segregated due to their generally low abundance values and species number (less than $5 \%$ of the total
TABLE 5. - Analysis of variance of the effects of the sampling date (Time) and the sampling Station on total microzooplankton abundance. (ns: $\mathrm{P}>0.05$; *: $\mathrm{P}<0.05$; ** $\mathrm{P}<0.01$ )

\begin{tabular}{|c|c|c|c|c|}
\hline Source of variation & Df & $\begin{array}{l}\text { microzooplankton } \\
\text { MS }\end{array}$ & $\mathrm{F}$ & $\mathrm{P}$ \\
\hline Time & 3 & 33.7292 & 107.54 & $* *$ \\
\hline Station & 2 & 0.6504 & 2.19 & ns \\
\hline Time $\mathrm{x}$ Station & 6 & 0.2972 & 0.95 & ns \\
\hline $\begin{array}{l}\text { Cochran's test } \\
\text { Transformation }\end{array}$ & & $\begin{aligned} & C= 0.181 \mathrm{P}>0.05 \\
& \operatorname{Ln}(x+1)\end{aligned}$ & & \\
\hline
\end{tabular}

species richness has been found in this station). The other two sheltered stations were characterised by high abundance values, but differed from each other 

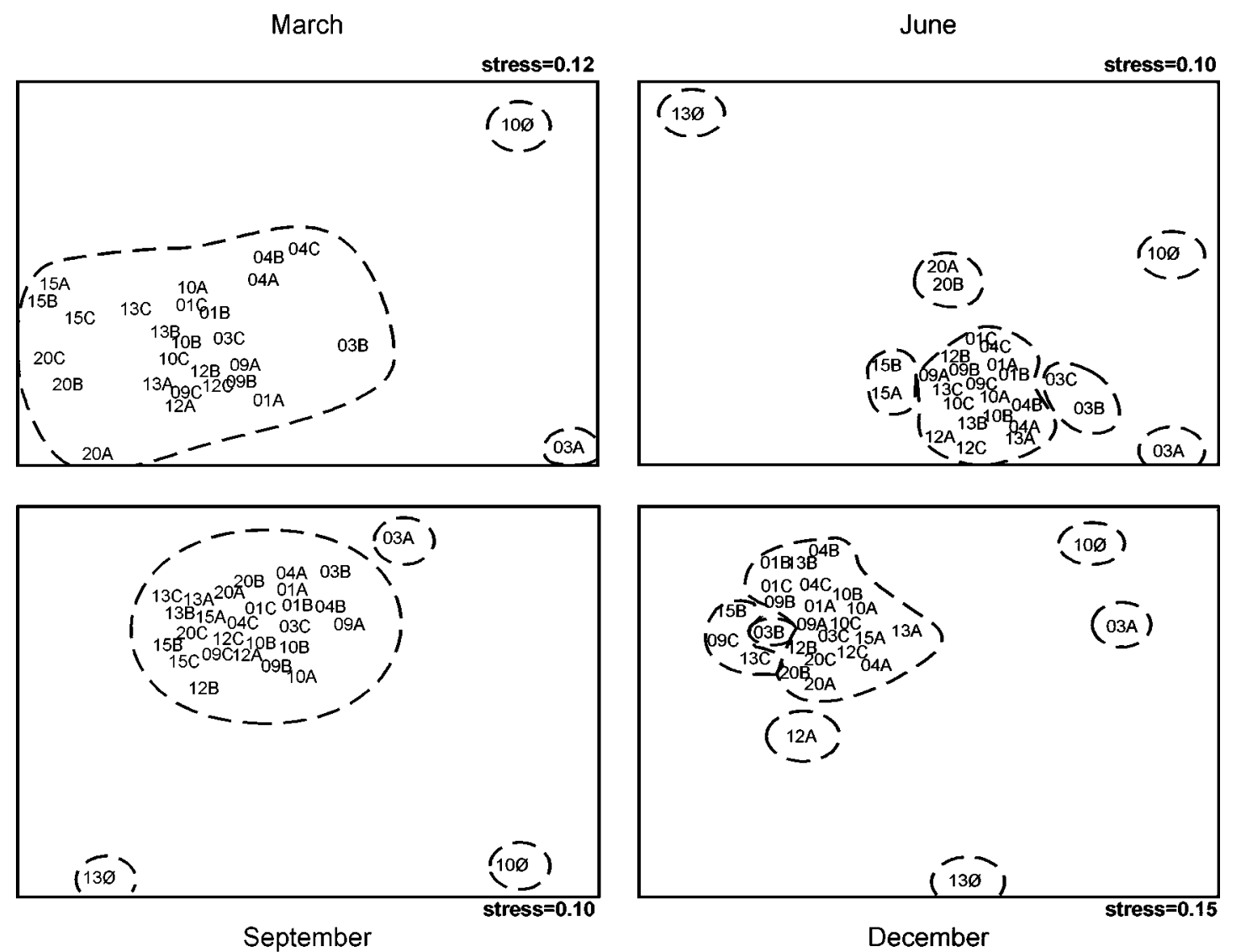

FIG. 5. - nMDS representation of microzooplankton samples collected in March, June, September and December 2000, with superimposed clusters at similarity level of $40 \%$ (dashed line). Numbers (01-20) represent transects. A, B, C, represent stations from near coast to open sea (at isobathes of $-10 \mathrm{~m},-20 \mathrm{~m},-50 \mathrm{~m}) . \varnothing$ indicates the confined station at Alimini (10) and Gagliano del Capo (13) transects. The confined station of Brindisi transect (harbour) is 03A.

in species composition. Alimini lake (T10 Ø) was characterised by the abundance of Polychaeta larvae (Spionidae) at all the seasons, and of the rotifer Synchaeta sp. in June and September. Tintinnina dominated the microzooplankton in Brindisi harbour (T03 A) during all the seasons, while Acartiidae and Oithona nauplii were particularly abundant in June and September.

\section{Resting stages}

A total of 87 resting stage morphotypes (49 identified at species level) were isolated from the 157 sediment samples (Table 6). Most of them (51) were ascribed to Dinophyta, 8 to Ciliophora, 5 to Rotifera, 3 to Copepoda, and 1 to Chrysophyta; 16 presumably protistan cysts and 3 metazoan resting eggs remained unidentified. Among Dinophyta, 37 cyst types were classified at least at the genus level. The other 14 were ascribed to Dinophyta thanks to the presence of such features as the typical red spot in the viable cysts or the presence of the archeopyle in the empty ones.
The total abundance of resting stages ranged from $1.1 \pm 0.1$ (average \pm SD) (T20 C, $-50 \mathrm{~m}$, September) to $1,753 \pm 46.5$ cysts cm$~^{-3}$ (T03 A, harbour, September; Fig. 6). Generally localities (areas) differed from each other in cyst presence, and higher abundance values were recorded at the more coastal station (A) of each transect (Table 7).

There were not differences between the averages of total abundance in the two sampling periods. In fact, in March and September, the cyst concentrations along the Salento coast were estimated (average of 27 triplicate samples) $143 \pm 349$ and $132 \pm$ 361 cysts $\mathrm{cm}^{-3}$ respectively. At the two confined stations of Brindisi harbour and the Alimini lake, cyst abundance was extraordinary high, being 1,703 \pm 292, and $691 \pm 167$ cysts $\mathrm{cm}^{-3}$ respectively (average values of the two sampling dates). At these stations, also the highest values of species richness were recorded during both sampling periods. In fact, in Brindisi harbour 44 cyst morphotypes were collected in March and 36 in September, while in the Alimini lake there were 22 different cyst types in March and 21 in September. 
TABLE 6. - List of microplankton categories collected as resting stages in the sediments during the two oceanographic surveys (M=March, $\mathrm{S}=$ September 2000). Black dots indicate the presence of the category in at least one sample of each cruise. Asterisks indicate new records for the area.

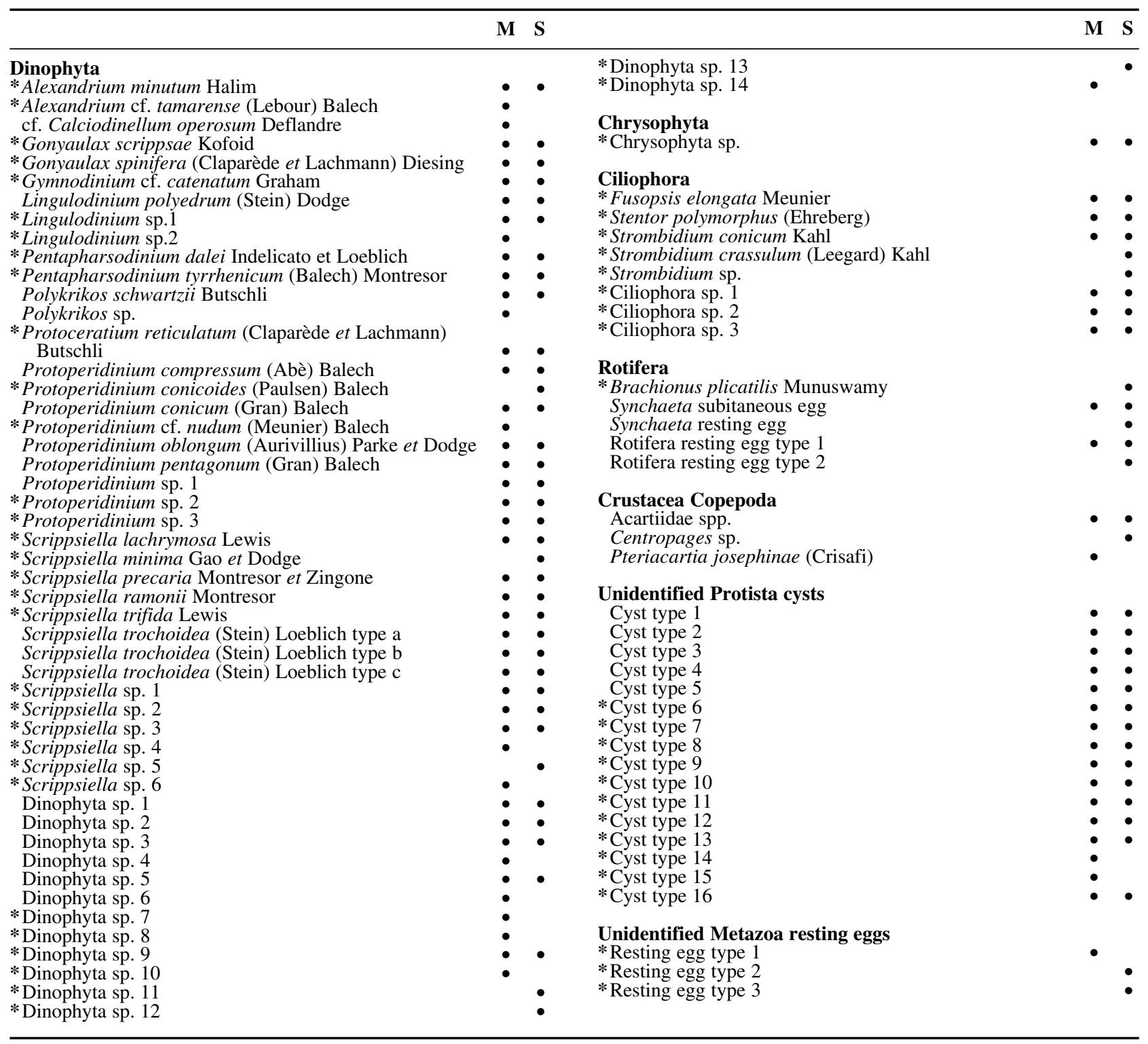

TABLE 7. - Analysis of variance of the effects of the locality and the station on resting stages abundance. (ns: $\mathrm{P}>0.05 ; *: \mathrm{P}<0.05 ; * * \mathrm{P}<0.01)$

\begin{tabular}{|c|c|c|c|c|c|c|c|c|}
\hline Source of variation & Df & $\begin{array}{l}\text { March } \\
\text { MS }\end{array}$ & $\mathrm{F}$ & $\mathrm{P}$ & Df & $\begin{array}{l}\text { eptember } \\
\text { MS }\end{array}$ & $\mathrm{F}$ & $\mathrm{P}$ \\
\hline locality & 4 & 3.3352 & 18.07 & $* *$ & 6 & 4.0257 & 15.97 & $* *$ \\
\hline station & 2 & 9.9847 & 54.10 & $* *$ & 2 & 7.2058 & 28.59 & $* *$ \\
\hline locality $\mathrm{x}$ station & 8 & 1.1239 & 6.09 & $* *$ & 12 & 1.9793 & 7.85 & $* *$ \\
\hline Cochran's test & \multirow{2}{*}{\multicolumn{3}{|c|}{$\begin{array}{c}\mathrm{C}=0.243 \mathrm{P}>0.05 \\
\text { None }\end{array}$}} & \multirow{2}{*}{\multicolumn{5}{|c|}{$\begin{array}{c}\mathrm{C}=0.249 \mathrm{P}>0.05 \\
\text { None }\end{array}$}} \\
\hline Transformation & & & & & & & & \\
\hline
\end{tabular}

In Brindisi harbour (T03 A), more than the $72 \%$ of the total cyst types found in the entire study area were collected. In this station, among Dinophyta, cysts of Lingulodinium polyedrum were very abun- dant, both in March and September, while cysts of Scrippsiella ramonii were abundant only in March and those of $S$. precaria and $S$. trochoidea only in September. One cyst type of Ciliophora (Ciliophora 


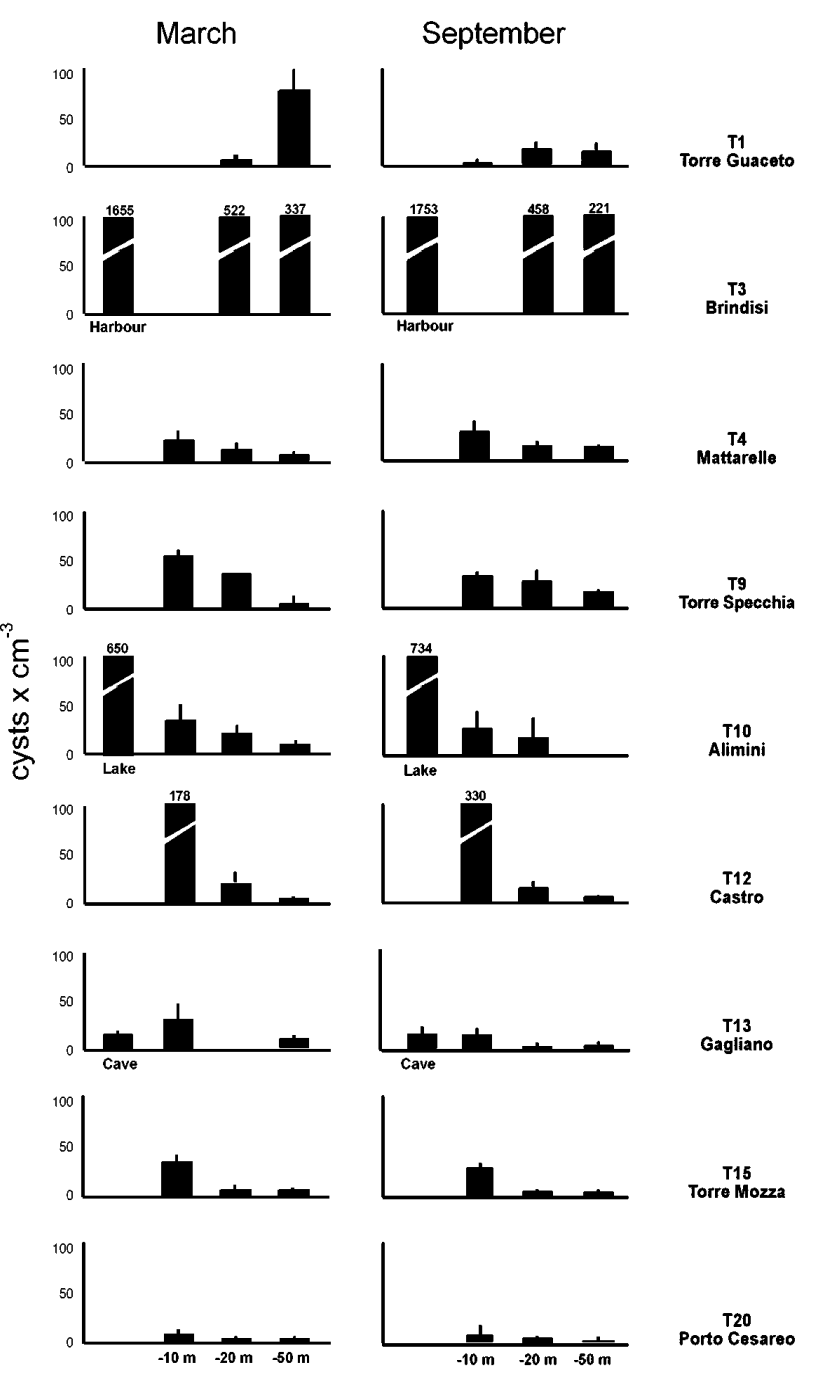

FIG. 6. - Resting stage abundance (all categories, cysts per $\mathrm{cm}^{3}$ of wet sediment) at 9 areas along the Salento Peninsula, during March and September 2000. sp.2) was abundant particularly in September while, among the Metazoa, the spiny resting eggs of Acartiidae (Copepoda) were abundant in March.

In the Alimini lake (T10 $\varnothing)$, high amounts of $S$. trochoidea (Dinophyta) cysts (Fig. 8n) were collected in September, and two egg types of Synchaeta sp. (Rotifera) were found; a smooth one (Fig. 8p) in March, and one with a rough surface (Fig. 8o) in September. Only Scrippsiella trochoidea cysts were widespread (even not ubiquitous) across the entire study area (86\% of samples in September) and, together with other 56 categories, they were collected during both sampling periods.

Multivariate analysis on resting stage data showed that the cyst assemblage in the sediments of the Brindisi transect (T03 A, B, C) and the Alimini lake station $(\mathrm{T} 10 \varnothing)$ were different, but also other stations segregated (Fig. 7), probably affected by the different abundance of the calcareous cysts of some Scrippsiella species (S. cf. lachrymosa, $S$. precaria, S. ramonii, S. trochoidea) together with those of Lingulodinium polyedrum, Protoperidinium conicum, and Ciliophora sp.1.

Cysts produced by several Tintinnina species have been observed also in the plankton samples during all seasons, particularly at T03, T04, and T09 transects, still in the lorica of the active stage (Fig. 8 a-h).

At Brindisi (T03) and Alimini (T10) transects, both in March and September, cysts of the potentially toxic dinoflagellates Alexandrium minutum, Gymnodinium catenatum, and Protoceratium reticulatum, together with those of the blooming species Lingulodinium polyedrum were collected. The two
March

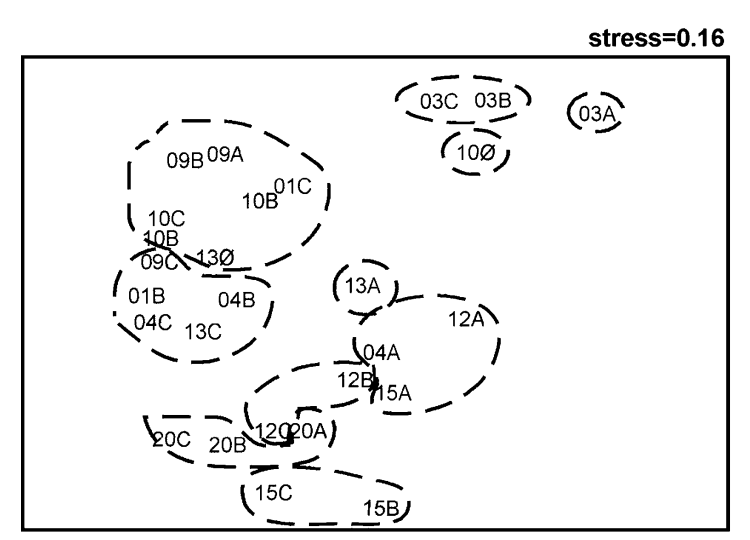

September

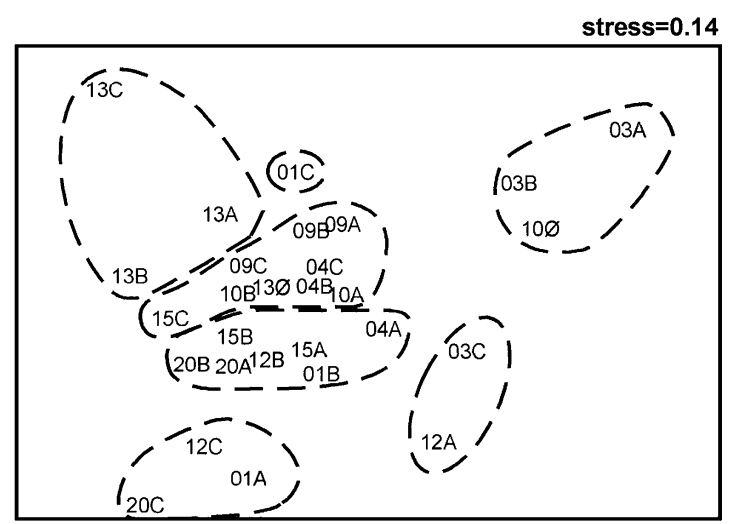

FIG. 7. - nMDS representation of resting stage samples collected in March and September 2000, with superimposed clusters at similarity level of $40 \%$ (dashed line). Numbers (01-20) represent transects. A, B, C, represent stations from near coast to open sea (at isobaths of -10m, 20m, $-50 \mathrm{~m}) . \varnothing$ indicates the confined station at Alimini (10) and Gagliano del Capo (13) transects. The confined station of Brindisi transect (harbour) is 03A. 

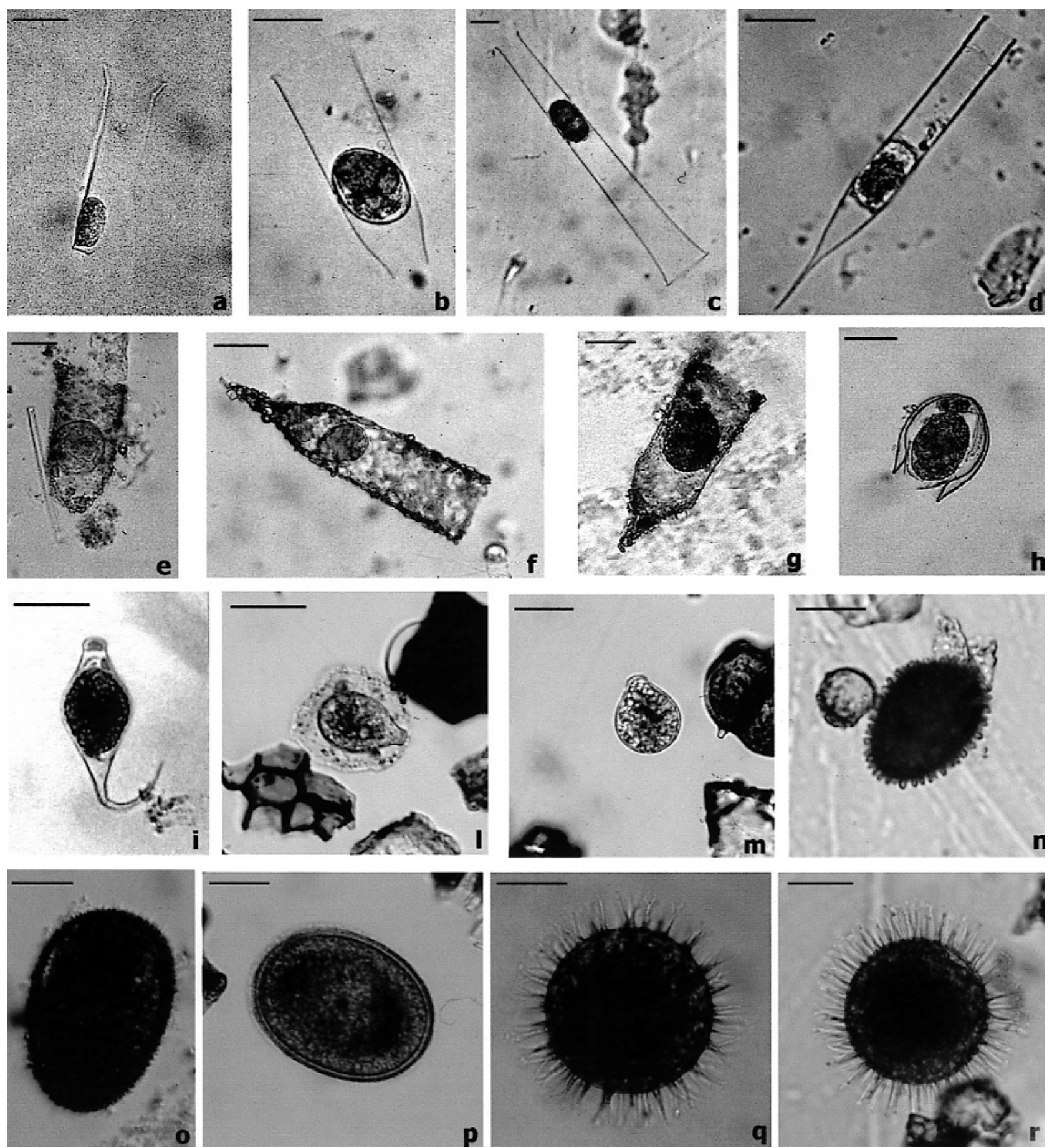

FIG. 8. - Resting stages of plankton organisms, collected along the Salento coasts both in the water column and in the sediments. a-n, Protoctista; o-r, Metazoa. a-h, cysts from the water column; i-r, from the sediment. a, Amphorides quadrilineata minor; b, Eutintinnus apertus; c, E. fraknoi; d, Helicostomella subulata; e, Tintinnopsis beroidea; f, T. cylindrica; g, T. lindeni; h, Undella claparedei; i, Fusopsis elongata; 1, Strombidium conicum; m, S. crassulum; n, Scrippsiella trochoidea; o, Synchaeta sp. (rough egg); p, Synchaeta sp. (smooth egg); q-r, Acartiidae spiny eggs. Scale bar: $30 \mu \mathrm{m}$.

latter species were found also at Mattarelle (T04) in September. At Castro coastal station (T12 A), a few cysts of Alexandrium tamarense, another PSP dinoflagellate, were collected in March.

Finally, at least 16 of the collected Dinophyta cyst types belong to species not found in the water column during the present investigation. Moreover, 25 cysts of Dinophyta, 8 of Ciliophora, 1 of Chrysophyta, and 1 of Rotifera were new records for the study area (Table 6) as well as 14 unidentified types. 
TABLE 8. - Number of Dinophyta taxa found in the water column as active stages (Pelagos), in the sediments as cysts (Benthos), and in both habitats, during March and September 2000 surveys along the Salento Coast.

\begin{tabular}{|c|c|c|c|c|}
\hline & Pelagos & Pelagos and benthos & Benthos & Total \\
\hline \multicolumn{5}{|l|}{ March 2000} \\
\hline $\begin{array}{l}\text { Identified species } \\
\text { Not identified taxa } \\
\text { Total }\end{array}$ & $\begin{array}{c}24(48 \%) \\
7 \\
31(42.5 \%)\end{array}$ & $\begin{array}{l}6(12 \%) \\
6(8.2 \%)\end{array}$ & $\begin{array}{c}20(40 \%) \\
16 \\
36(49.3 \%)\end{array}$ & $\begin{array}{l}50 \\
23 \\
73\end{array}$ \\
\hline \multicolumn{5}{|l|}{ September 2000} \\
\hline $\begin{array}{l}\text { Identified species } \\
\text { Not identified taxa } \\
\text { Total }\end{array}$ & $\begin{array}{c}27(46 \%) \\
5 \\
36(44 \%)\end{array}$ & $\begin{array}{l}6(9 \%) \\
6(7 \%)\end{array}$ & $\begin{array}{c}30(45 \%) \\
10 \\
40(49 \%)\end{array}$ & $\begin{array}{l}67 \\
15 \\
82\end{array}$ \\
\hline
\end{tabular}

\section{Benthic-pelagic coupling}

Among Dinophyta, many species were found as cysts in the sediments, but not as active stages in the water column. In March, for example, of the 50 species totally collected, 26 were found as cysts in the sediments, and only 6 of them were found also as active stages in the water column. Therefore in this period, the $40 \%$ of the Dinophyta species richness was resting in the sediments. In September, 67 species were totally collected, and 30 of them only as cysts, corresponding to the $45 \%$ of the total species richness (see Table 8). Most of the Dinophyta species collected exclusively in the water column are not known as cyst producers. In fact, only 4 (on a total of 24) of the species found in March produce cysts, and 4 out of the 27 found in September.

In the Alimini lake, the microzooplankton was dominated by Spionidae larvae (Polychaeta) which have adults in the benthos, and Synchaeta sp. (Rotifera). The rotifer (found in the water column of the lake only in June and December) was present with two types of eggs in the sediments (Fig. 8 o, p). The smooth type (subitaneous) was found in March $\left(32.9 \pm 8.5 \mathrm{eggs}^{-3}\right)$ and the rough one (resting or diapausal) in September (11.7 \pm 7.1 eggs $\mathrm{cm}^{-3}$; Fig. 9a).

In Brindisi harbour sediments, a high density of Acartiidae spiny eggs (diapausal) (Fig. $8 \mathrm{q}, \mathrm{r}$ ) was recorded in March $\left(89.7 \pm 29\right.$ eggs $\left.\mathrm{cm}^{-3}\right)$. In the water column of the harbour, the Acartiidae nauplii population grew from 42.9 ind. $1^{-1}$ in March, to 168.4 ind. $1^{-1}$ in June, and dropped nearly to zero in September and December. Correspondingly, the resting egg density decreased more than 50\% from March to September (Fig. 9b).

Together with Copepoda nauplii, Ciliophora were dominant in the microzooplankton of the Brin-
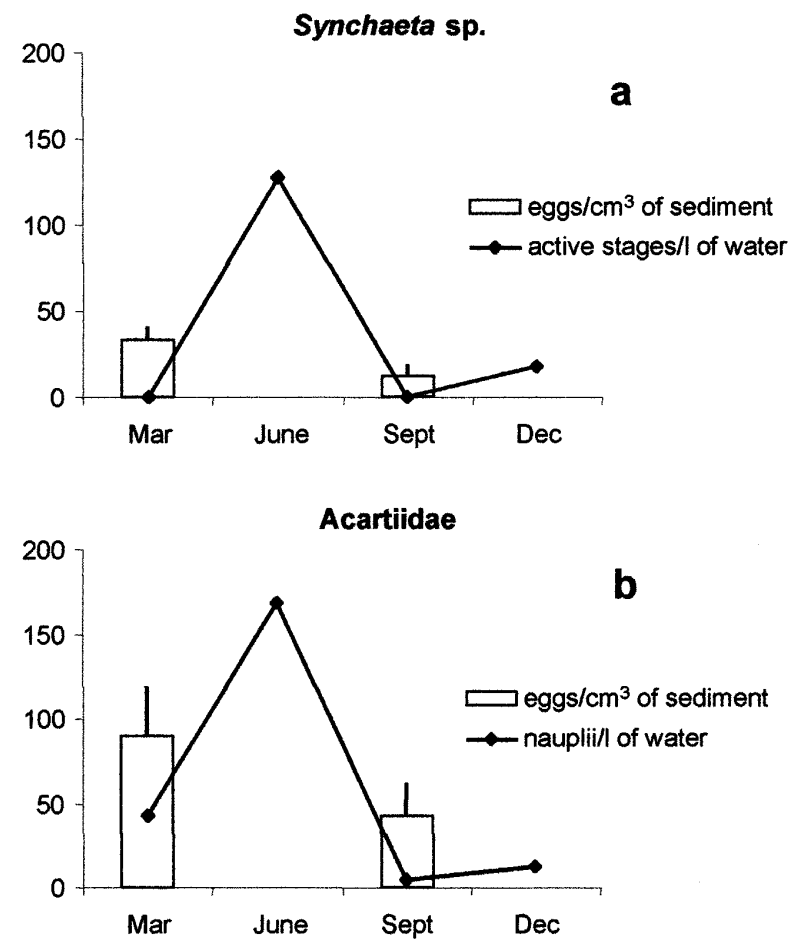

FIG. 9. - Abundance of active stages (in the water column) and eggs (in the sediments) of: (a) Synchaeta sp. (Rotifera) in the Alimini Lake, and (b) Acartiidae nauplii (Copepoda Calanoida) in the Brindisi Harbour.

disi harbour: four types of unidentified Ciliophora cysts (Fig. 8 i, m), with the typical flask-shaped morphology, were found in the sediments. One of them is produced by Strombidium sp. Active stages of $S$. acutum were found in the water column.

\section{DISCUSSION}

Here a seasonal study on microplankton communities and the resting stage assemblages in the bottom sediments was carried out. In all the compart- 
ments studied (phytoplankton, microzooplankton, resting stages) none of the more than 400 identified categories were found in all the samples in the same season. In addition, only a small percentage (31\% of phytoplankton, $19 \%$ of microzooplankton) of plankton categories were found at all times, at least in one sample. These data well describe the strong variability in composition, over time, of the coastal plankton community. If, on the other hand, we consider the composition of the cyst-assemblages (obviously taking into account the different number of sampling times) a higher stability emerges in comparison. Only considering March and September, in fact, $53 \%$ of phytoplankton categories, and $35 \%$ of microzooplankton were present in both sampling dates, against the $64 \%$ of cyst types.

This result is probably due to the long residence time of the resting stages in the sediments, highlighting the importance of this compartment for biodiversity estimates, since it can provide the information missing in a study of the plankton compartment.

The microzooplankton, among the considered communities, was the best habitat descriptor, it being possible to separate confined stations (harbour, and lake) from the more exposed coastal stations on the basis of its distribution. This was probably due to the presence of characteristic microplankters for those environments (e.g. tintinnids $F$. serrata, $H$. subulata, $T$. beroidea, $T$. cincta, T. cylindrica, T. karajacensis, T. lobiancoi in Brindisi harbour, and rotifers or Polychaeta larvae in the Alimini lake), often being absent from the other stations.

Near-shore stations were characterised by higher values of cyst abundance, possibly correlated with the degree of shelter or confinement (sensu Guelorget and Perthuisot, 1992) of the environment (see also Lindley, 1990; Marcus 1995; Belmonte et al., 1995; Rubino et al., 2000). This general trend probably derives from the fact that plankton populations show higher density and, generally, higher number of cyst-producing species (this strategy seems typical for coastal plankton) in more coastal and/or surface environments (see Williams-Howze, 1997, for calanoids), where this life cycle trait is an adaptation to seasonal variability. In addition, low oxygen concentrations, which occur in muddy sediments of confined areas, could play a role in the storage/accumulation of cysts, by either lowering the excystment rate (Lutz et al., 1992), or by facilitating predator avoidance (Persson, 2000).
Two of the sheltered stations of the present study hosted thousands of cysts per $\mathrm{cm}^{3}$ of sediment. Such cyst assemblages confirm the role as biodiversity reservoirs for these environments. The plankton communities are heavily influenced by these cyst banks and receive their recruits from them (the "supply vertical ecology" of Marcus and Boero, 1998).

In many cases the most abundant species in the water column, in each period, were not the same as those which dominated (as cysts) the sediment samples. Most of the Dinophyta species, which were collected exclusively in the water column, are not known as cyst producers. In fact, only 4 out of the 24 exclusively planktonic species found in March produce cysts, and 4 out of the 27 species found in September. In the cases of Synchaeta sp. (Rotifera) and Acartiidae (Copepoda), an inverse correlation was evident between the presence of active stages in the water column and resting eggs in the sediments. For Synchaeta sp., only an egg with a rough surface can be considered as "resting" (see Belmonte et al., 1997). Hence the presence of resting eggs in the sediment in September, during a period of absence of the active stages in the water column, corresponds to a typical habitat switch of the rotifer population which could have September as its programmed resting period. The absence of active rotifers in March could be interpreted as the occurrence of an unpredictable adverse condition which has been overcome as a non specialised resting stage (quiescent egg). In fact, this type of egg (smooth surface) should be parthenogenetic, hence produced during a "bloom" phase, and it is able to wait for the return of conditions suitable for active stages (see Fig. 9a). The inverse correspondence is even more evident for Acartiidae (Fig. 9b). Abundance of nauplii in the water column is low when resting eggs have been found in the sediment.

It was not possible to establish the same correlation for Dinophyta, probably due to their shorter life cycle (not tuned to the present seasonal sampling), and their complex encystment-germination cycles (see Ishikawa and Taniguchi, 1996; Kim and Han, 2000, for Scrippsiella cycles).

A correlation between the presence of ciliates in the plankton and their cysts in the sediments was not evident. However, this could be due to inadequate knowledge of ciliate life cycles and of their cyst morphology. Among ciliates, Tintinnina were very abundant, but although they produce cysts (as also demonstrated by direct observation in the present study, see Fig. 8) their presence in the cyst assem- 
blage was not evident. The possibility that they undergo a metamorphosis after sedimentation and their chitinous lorica dissolves (see Reid, 1987, for cysts of the non-loricate Strombidium crassulum) might be one reason for the poor correlation between bottom morphotypes and water column ones.

The active stages of many cysts were not found in the water column. This suggests that these species could have been dominant in the past, and/or could return to the plankton community in the future. In this framework, we must consider that, although minimal, a percentage of cysts can rest for periods longer than one simple adverse season (Hairston et al., 1995; Belmonte et al., 1999) according to a bethedging strategy that avoids complete local extinction of some species (see Philippi and Seger, 1989).

In general, the study of sediments adds information and discussion points to the study of plankton. The "traditional approach" to plankton studies can lead to information loss, of as much as 50\% in the case of Dinophyta in the present study.

An integrated water/sediment approach, as the one performed here, gives us more complete information about plankton composition and dynamics. The knowledge of life cycles, however, is still primitive (especially in the field of cyst production) and needs to be refined to fully understand the processes that underlie the patterns of plankton dynamics.

\section{ACKNOWLEDGEMENTS}

The present study has been funded by INTERREG II Greece-Italy Programme, the Italian Ministry of University and Research (MIUR, 60\% and COFIN projects) and the National Council for Research (CNR). It utilised structures and material from Initiative 22 of the Catania-Lecce project, $5 \mathrm{C}$ 60 Program of the Italian Ministry of Agricultural Policy (MiPA), and the Provincia di Lecce. We thank the crew of Coopernaut, and Christian Vaglio, for field assistance, and Antonio Agrimi for disentangling administration.

\section{REFERENCES}

Belmonte, G., P. Castello, M.R. Piccinni, S. Quarta, F. Rubino, S. Geraci and F. Boero -1995. Resting stages in marine sediments off the Italian coast. In: A. Elefteriou, A.D. Ansel and C.J. Smith (eds.), Biology and ecology of shallow coastal waters, pp. 53-58. Olsen and Olsen, Fredensborg.

Belmonte, G., A. Miglietta, F. Rubino and F. Boero. - 1997. Morphological convergence of resting stages produced by planktonic organisms: a review. Hydrobiologia, 335(1/3): 159-165.
Belmonte, G., P. Pirandola, S. Degetto and F. Boero. - 1999. Abbondanza, vitalità e distribuzione verticale di forme di resistenza nei sedimenti del Nord Adriatico. Biol. Mar. Medit., 6 (1): 172-178.

Boero, F. - 1994. Fluctuations and variations in coastal marine environments. Mar. Biol., 15: 3-25.

Boero, F., G. Belmonte, G. Fanelli, S. Piraino and F. Rubino. 1996. The continuity of living matter and the discontinuities of its constituents: do plankton and benthos really exist? Trends Ecol. Evol., 11 (4): 177-180.

Bros, W.E. and B.C. Cowell. - 1987. A technique for optimising sample size (replication). J. Exp. Mar. Biol. Ecol., 114: 63-71.

Clarke, K.R. and R.M. Warwick. - 1994. Change in marine communities: an approach to Statistical Analysis and Interpretation. Natural Environment Research Council, UK.

Dale, B. - 1983. Dinoflagellate resting cysts: benthic plankton. In: G.A. Frixel (ed.), Survival Strategies of the Algae, pp. 69-136. Cambridge University Press. Cambridge.

Della Tommasa, L., G. Belmonte, A. Palanques, P. Puig, and F. Boero. - 2000. Resting stages in a submarine canyon: a component of shallow-deep-sea coupling? Hydrobiologia, 440: 249-260.

Giangrande, A., S. Geraci and G. Belmonte. - 1994. Life-cycle and life-history diversity in marine invertebrates and the implications in community dynamics. Oceanogr. Mar. Biol. Ann. Rev., 32: 305-333.

Guelorget, O. and J.P. Perthuisot. - 1992. Paralic ecosystems. Biological organization and functioning. Vie Milieu, 42: 215-251.

Hairston, N. Jr, R.A. van Brunt, C.N. Kearns and D.R. Engstrom. 1995. Age and survivorship of diapausing eggs in a sediment egg bank. Ecology, 76: 1706-1711.

Ishikawa, A. and A. Taniguchi. - 1996. Contribution of benthic cysts to the population dynamics of Scrippsiella spp. (Dinophyceae) in Onagawa Bay, northeast Japan. Mar. Ecol. Prog. Ser., 140: 169-178.

Kim, Y. O. and M. S. Han - 2000. Seasonal relationships between cyst germination and vegetative population of Scrippsiella trochoidea (Dinophyceae). Mar. Ecol. Prog. Ser., 204: 111-118.

Krsinic, F. - 1998. Vertical distribution of protozoan and microcopepod communities in the South Adriatic Pit. J. Plankton Res., 20: 1033-1060.

Leck, M.A., V.T. Parker and R.L. Simpson (eds.). - 1989. Ecology of soil seed banks. Academic Press, San Diego.

Lindley, J.A. - 1990. Distribution of overwintering calanoid copepod eggs in sea bed sediments of the English Channel and southern North Sea. J. Plankton Res., 8: 399-400.

Lindley, J.A. - 1992. Resistant eggs of the Centropagoidea (Copepoda: Calanoida): a possible preadaptation to colonization of inland waters. J. Crust. Biol., 12(3): 368-371.

Lutz R.V., Marcus N.H. and J.P. Chanton - 1992. Effects of low oxygen concentrations on the hatching and viability of eggs of marine calanoid copepods. Mar. Biol., 114: 241-247.

Marcus, N.H. - 1990. Calanoid copepod, cladoceran and rotifer eggs in sea-bottom sediments of northern Californian coastal waters: identification, occurrence and hatching. Mar. Biol., 105: 413-418.

Marcus, N.H. - 1995. Seasonal study of planktonic copepods and their benthic resting eggs in northern California coastal waters. Mar. Biol., 123: 459-465.

Marcus, N.H. and F. Boero. - 1998. Production and plankton community dynamics in coastal aquatic systems: the importance of benthic pelagic coupling in the forgotten role of life cycles. Limnol. Oceanogr., 43: 763-768.

Marcus, N.H., R. Lutz, W. Burnett and P. Cable. - 1994. Age, viability and vertical distribution of zooplankton resting eggs from an anoxic basin: evidence of an egg bank. Limnol. Oceanogr., 39(1): 154-158.

Matsuoka, M. and Y. Fukuyo - 2000. Technical guide for modern dinoflagellate cyst study. WESTPAC-HAB/WESTPAC/IOC.

Montresor, M., A. Zingone and D. Sarno. - 1998. Dinoflagellate cyst production at a coastal mediterranean site. J. Plankton Res., 20: 2291-2312.

Nehring, S. - 1997. Dinoflagellate resting cysts from recent German coastal sediments. Bot. Mar., 40: 307-324.

Persson, A. - 2000. Possible predation of cysts - a gap in the knowledge of dinoflagellate ecology? J. Plankton Res., 22: 803-809.

Philippi, T. and J. Seger. - 1989. Hedging one's evolutionary bets, revisited. Trends Ecol. Evol., 4(2): 41-44. 
Reid, P.C. - 1987. Mass encystment of a planktonic oligotrich ciliate. Mar. Biol. 95: 221-230.

Rubino, F., O.D. Saracino, G. Fanelli, G. Belmonte, A.M. Miglietta and F. Boero. - 1998. Life cycles and pelagos-benthos interactions. Biol. Mar. Medit., 5: 253-257.

Rubino, F., G. Belmonte, A.M. Miglietta, S. Geraci and F. Boero. 2000. Resting stages of plankton in Recent North Adriatic sediments. Mar. Ecol. P.S.Z.N.I, 21(3-4): 263-284.

Rubino, F., S. Moscatello, O.D. Saracino, G. Fanelli, G. Belmonte and F. Boero. -2002 . Plankton derived resting stages in marine coastal sediments along the Salento Peninsula (Apulia, South Eastern Italy). Mar. Ecol. P.S.Z.N.I., 23(Suppl. 1): 329-339.

Utermöhl, H. - 1958. Zur Vervolkommung der quantitativen Phy- toplankton Methodik. Mitt. Int. Ver. Theor. Angew. Limnol., 9: $1-38$

Uye, S.-I. - 1985. Resting egg production as a life-cycle strategy of marine planktonic copepods. Bull. Mar. Sci., 37(2): 440-449.

Williams-Howze J. - 1997. Dormancy in the free living copepod orders Cyclopoida, Calanoida, and Harpacticoida. Oceanogr. Mar. Biol. Ann. Rev., 35: 257-321.

Winer, B.J. - 1971. Statistical principles in experimental design. Mc Graw-Hill Kogakusha, Tokyo.

Zingone, A., M. Montresor and D. Marino. - 1990. Summer phytoplankton physiognomy in coastal waters of the Gulf of Naples. Mar. Ecol., 2: 157-172. 